\title{
Diversity Analysis and Assessment of Association of SSR Markers to Late Leaf Spot and Rust Resistance in Groundnut (Arachis hypogaea L.)
}

\author{
Anamika Roy ${ }^{1}$, M. Lal Ahamed ${ }^{2 *}$, Y. Amaravathi ${ }^{3}$, K. Viswanath $^{4}$, \\ J.P.B. Dayal ${ }^{1}$ and B. Sreekanth ${ }^{5}$ \\ ${ }^{1}$ Department of Genetics and Plant Breeding, ${ }^{5}$ Department of Crop Physiology, Agricultural \\ College, ANGRAU, Bapatla, Andhra Pradesh, India \\ ${ }^{2}$ Department of Molecular Biology and Biotechnology, ANGRAU, APGC, Lam, Guntur, \\ Andhra Pradesh, India \\ ${ }^{3}$ Department of Plant Molecular Biology and Biotechnology, ${ }^{4}$ Department of Plant Pathology, \\ IFT, RARS, ANGRAU, Tirupati, Andhra Pradesh, India \\ *Corresponding author
}

\section{A B S T R A C T}

\begin{tabular}{|l|}
\hline K e y w o r d s \\
$\begin{array}{l}\text { Groundnut, SSR } \\
\text { markers, Diversity, } \\
\text { Association, Late } \\
\text { leaf spot, Rust, PIC }\end{array}$ \\
\hline Article Info \\
\hline $\begin{array}{l}\text { Accepted: } \\
\text { 20 July 2018 } \\
\text { Available Online: } \\
\text { 10 August } 2018\end{array}$ \\
\hline
\end{tabular}

\section{Introduction}

Groundnut (Arachis hypogaea L.) is one of the most important oilseed crops belonging to legume family Fabaceae. The main economic part is seed and is valued for its polyunsaturated fatty acid containing oil with longer shelf life. Groundnut is a segmental allopolyploid originated recently from a cross between two diploid species and spontaneous
Groundnut is an important oilseed crop of India and biotic stresses cause heavy yield losses. Development of resistant cultivars is one of the important objectives of the maintenance breeding programmes of groundnut and utilization of molecular markers for identification resistant sources has become a handy tool for plant breeders. Keeping this in view, an experiment was carried to check the resistance source(s) against late leaf spot (LLS) and rust in 30 genotypes under field conditions. Screening revealed that seven genotypes were moderately resistant to LLS and five genotypes were moderately resistant to rust. Out of thirty SSR markers, 16 recorded allelic variation and the polymorphic information content (PIC) value ranged from 0 - 0.84. The SSR markers, IPAHM103, cosegregated with LLS and rust phenotype and PM375 showed general resistance to a wide variety of biotic stresses. Thus, these markers can be used for identification and transfer of positive alleles for these biotic stresses in molecular breeding programmes. 
various biotic and abiotic stresses. Among the biotic stresses, two foliar diseases viz. Late leaf spot (LLS, causal organism Phaeoisariopsis personata) and rust (causal organism Puccinia arachidis) cause more than $50 \%$ yield losses (Subrahmanyam et al., 1989), These two diseases occur simultaneously and drastically reduce the yield and quality of haulm. Thus, it necessitated for the identification and utilization of resistant sources in the breeding programmes. The conventional plant breeding programmes aimed to identify the resistance for these diseases led to the confusing results because of the recessive and polygenic nature of resistance of these diseases and making the identification of resistant and susceptible lines very tedious and time consuming (Tiwari et al., 1984; Paramasivam et al., 1990 and Bromfield and Bailey, 1972).

Application of molecular tools is important for the precise identification and transfer of the genes to the cultivated lines. Many DNA based molecular markers such as RAPDs, RFLP, SCARs, AFLP, SSR etc. have been used for molecular characterization of groundnut (Cuc et al., 2008 and OtengFrimpong et al., 2015). Among the different molecular marker systems available, simple sequence repeat (SSR) markers are the potential markers as they are hyper-variable than any other markers identified in groundnut and are co-dominant (Gupta and Varshney, 2000; Ferguson et al., 2004; He et al., 2005 and Mace et al., 2006). Validation of the markers already reported for resistance in these genotypes will speed up the process of introgression of rust and LLS resistance gene(s) into preferred peanut genotypes through their planned deployment in molecular breeding programme (Sujay et al., 2012).

In the present study attempts were made to screen thirty groundnut genotypes under field conditions to identify the resistance sources against LLS and rust, and also know the genetic relatedness and diversity of the genotypes using SSR markers along with the association of these markers to resistance against LLS and rust.

\section{Materials and Methods}

\section{Plant material}

In the present study, fourteen genotypes collected from Indian Institute of Groundnut Research (IIGGR), Junagadh, Gujarat, India and sixteen are the released varieties and advanced breeding lines developed at Regional Agricultural Research Station, Tirupati, Andhra Pradesh, India along with two susceptible checks (TMV 2 and Narayani) and one resistant check (ICGV 03042), were screened for resistance to LLS and rust in two separate field experiments during rabi 2016-2017.

The genotypes were sown in two separate replicated trials following infector row technique. In order to get uniform disease spread and optimum disease pressure, late leaf spot conidia and rust spores were isolated by soaking and rubbing the collected infected leaves and inoculating above with the help of sprinklers for three successive days at 45 DAS. The disease severity was also increased by maintaining high humidity in the field through the sprinkling of water around the infected plants and covering them with polythene sheets during the nights for seven days. Further, infected leaves were dumped at the base of the plants in order to increase the disease pressure.

\section{Disease phenotyping}

Observations for rust and LLS were recorded as per modified 9 point scale suggested by Subrahmanyam et al., (1995) at 70, 80, 90 
and 106 days after sowing (DAS). Disease severity data was collected from five randomly selected plants from each genotype of the replications. The disease severities corresponding to the rust and LLS scores are $1=0 \% ; 2=1-5 \% ; \quad 3=6-10 ; 4=11-20 \%$; $5=21-30 \% ; 6=31-40 \% ; 6=31-40 \% ; 7=41-$ $60 \% ; 8=61-80 \%$ and $9=81-100 \%$. Based on the severities, the genotypes were differentiated as resistant (score of <3); moderately resistant (score of 4 and 5); susceptible (score of 6 and 7) and highly susceptible (score of 8 and 9) (Sudini et al., 2015).

\section{Plant genomic DNA isolation and quantification}

Genomic DNA was extracted from young unexpanded leaves using CTAB method (Doyle and Doyle 1990) with few modifications. The modifications include use of Polyvinylpyrrolidone (PVP) in preparation of CTAB extraction buffer, RNAse treatment before precipitation step and use of $90 \%$ ethyl alcohol and sodium chloride for precipitation of DNA in place of isopropanol and sodium acetate. The quality of DNA was checked on $0.8 \%$ agarose gel after staining with ethidium bromide and quantified by nanodrop spectrophotometer (Thermoscientific, ND1000). DNA was diluted with autoclaved milliQ water to a working concentration $50 \mathrm{ng} / \mu \mathrm{l}$ and was subsequently used for SSR analysis.

\section{PCR amplification}

Polymerase chain reaction was carried out using 30 SSR markers in a reaction volume of $10 \mu \mathrm{l}$ containing 50ng/ $\mu \mathrm{l}$ DNA, 10 picomole of each forward and reverse SSR primers, $1 \mu 1$ of $10 \mathrm{X}$ assay buffer, $2 \mathrm{mM}$ of $\mathrm{MgCl}_{2}, 0.25$ $\mathrm{mM}$ of dNTPs, $0.05 \mathrm{U}$ Taq DNA polymerase and suitable amount of sterile deionized water. PCR amplifications were performed in a thermal cycler (Eppendorf Vapo Protect) with the thermal profile of initial denaturation at $94^{\circ} \mathrm{C}$ for $3 \mathrm{~min}$ followed by 35 cycles of denaturation at $94^{\circ} \mathrm{C}$ for $30 \mathrm{sec}$, primer annealing at specific annealing temperature of each primer for $30 \mathrm{sec}$ and extension at $72^{\circ} \mathrm{C}$ for $1 \mathrm{~min}$ and a final extension at $72^{\circ} \mathrm{C}$ for 5 min. The amplified products were separated on $4 \%$ agarose $(3.75 \%$ MetaPhor agarose + $0.25 \%$ agarose) containing Ethidium Bromide and visualized under UV light (Gel Doc $^{\mathrm{TM}} \mathrm{XR}+\mathrm{Gel}$ Documentation System, Biorad).

\section{SSR analysis}

For data analysis, each band was defined as a single character. The alleles were scored and converted into ' 1 ' and ' 0 ' matrix, of which ' 1 ' indicated the presence and ' 0 ' indicated absence of the allele and thereby developed a binary digit format for 30 SSR markers included in the study. Polymorphic information content (PIC) of each SSR marker was calculated using the formula suggested by Anderson et al., (1993).

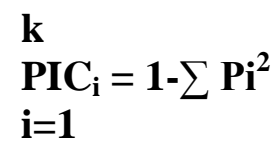

Where, $\mathrm{k}$ is the total number of alleles (bands) detected for one SSR locus and $i$ is the proportion of the genotypes containing the allele (band) in all the samples analyzed.

The genetic distance for all pair wise combinations of groundnut genotypes were calculated using Jaccard's similarity coefficient (Jaccard, 1908).

Dendrogram was constructed using software SPSS (ver. 20, IBM software 2009, Norusis, 2004). The option average linkage between groups was employed. 


\section{Results and Discussion}

The thirty genotypes along with the resistant and susceptible checks were evaluated for LLS and rust scoring in the field conditions. The resistant genotype, ICGV 03042, showed the disease scoring of 1 and 2 for LLS and rust, respectively, indicating high levels of resistance to these diseases (Table 1). The susceptible checks, TMV-2 and Narayani, were found highly susceptible to both LLS and rust. Among the studied genotypes, only seven (ICG 1710, ICG 1707, ICG 4248, ICG 1079, ICG 6475, ICG 1705 and ICG 4448) showed moderately resistance to LLS (disease scoring of 4 and 5) whereas five genotypes (ICG 1710, Bheema, ICG 6475, ICG 1079 and ICG 1707) were moderately resistant to rust (Table 1).

\section{SSR marker validation for diversity}

A total of 30 SSR markers are chosen based on their linkage to RGAs mostly rust and/or late leaf spot. Out of the thirty SSR markers used, 16 recorded allelic variations between 33 groundnut genotypes and the remaining 14 were monomorphic. Analysis for PIC with 30 SSR markers across 30 genotypes and three checks revealed that the PIC values of SSR markers in the present study ranged from 0 (monomorphic) to 0.84 (GM 2079) (Table 2). The markers viz., IPAHM103, PM377, GM 2079 and SEQ18G09, recorded high PIC values ranged from 0.75 to 0.84 . It is reported that PIC value of 0.70 and above is highly informative while PIC value from $0.44-0.70$ is moderately informative (Hildebrand et al., 1992).

The genetic distance calculated using Jaccard's similarity coefficient ranged from 0.26 (between Kadiri-9 and Bheema) to 0.64 (between Kalahasti and TCGS 1157). Dendrogram was constructed using UPGMA and the genotypes were grouped into three major clusters based on the amplification data of 16 markers using SPSS software (Fig 1). Cluster I had resistant check, ICGV 03042 and two susceptible genotypes together. Several studies previously reported grouping of susceptible and resistant genotypes under the same cluster (Gautami et al., 2009; Mondal and Badigannavar, 2010 and OtengFrimpong et al., 2015). The largest cluster formed with 17 genotypes (cluster II) had moderately resistant to susceptible genotypes and the third cluster was with four genotypes having susceptible reaction to LLS and rust except ICG 1705 which showed moderately resistant reaction to LLS. Gaikpa et al., (2015) also reported clustering of some varieties with similar reactions to leaf spot disease into the same group possibly suggest a common gene controlling resistance in those genotypes.

\section{Association of SSR marker with LLS and rust resistance}

Out of thirty SSR markers employed in the study, two markers (PM 375 and IPAHM103) co-seggregated with the LLS and rust phenotype (Fig 5). Marker IPAHM103 already reported as candidate gene for LLS and rust and is located on two chromosomes viz., $\mathrm{A} 03$ and $\mathrm{B} 03$ at 133.843 and 111.802 cM, respectively. The LLS and rust resistance contributing allele of IPAHM103 was $180 \mathrm{bp}$ (Fig 2 and 3).

The SSR, PM 375, already reported to be linked with LLS and rust, distinguished the moderately resistant genotypes along with resistant check (118 bp) and susceptible genotypes (105 bp) except for few genotypes like CS 19, TPT3, Kalahasthi and TCGS 1157 (Fig. 4). The CS-19 is a known resistance source for stem rot (Sclerotium rolfsii) and Kalahasthi is known resistant variety for kalahasthi malady (Tylenchorhynchus brevilineatus). 
Table.1 Disease reaction of genotypes to rust and late leaf spot in Groundnut

\begin{tabular}{|c|c|c|c|}
\hline $\begin{array}{l}\text { Disease } \\
\text { scale }\end{array}$ & $\begin{array}{c}\text { Disease } \\
\text { severity } \\
(\%)\end{array}$ & $\begin{array}{l}\text { Disease reaction to late leaf } \\
\text { spot }\end{array}$ & Disease reaction to rust \\
\hline 1 & 0 & ICGV 03042 (RC) & - \\
\hline 2 & $1-5$ & - & ICGV 03042 (RC) \\
\hline 3 & $6-10$ & - & - \\
\hline 4 & $11-20$ & ICG 1710, ICG 1707 & ICG 1710 \\
\hline 5 & $21-30$ & $\begin{array}{l}\text { ICG 4248, ICG 1079, ICG } \\
6475, \text { ICG 1705, ICG } 4448\end{array}$ & $\begin{array}{c}\text { Bheema, ICG 6475, ICG 1079, } \\
\text { ICG } 1707\end{array}$ \\
\hline 6 & $31-40$ & $\begin{array}{c}\text { Bheema, ICG 4477, ICG } \\
\text { 1384, ICG 4113, Kadiri-9, } \\
\text { Tirupati-2, Abhaya, } \\
\text { Tirupati-3, Tirupati-4, } \\
\text { Kalahasti, ICG } 7626\end{array}$ & $\begin{array}{l}\text { ICG 1705, ICG 4448, Kadiri-9, } \\
\text { Abhaya, ICG 4248, ICG } 7626\end{array}$ \\
\hline 7 & $41-60$ & $\begin{array}{c}\text { TCGS 1157, Dharani, } \\
\text { TCGS-1073, Prasuna, } \\
\text { Tirupati-1, Kadiri-6, } \\
\text { Greeshma, CS-19, ICG } \\
\text { 3608, ICG 3603, ICG } 1232\end{array}$ & $\begin{array}{l}\text { TCGS-1073, Prasuna, Tirupati-3, } \\
\text { Dharani, TirupatI-4, Kalahasti, } \\
\text { Tirupati-1, Kadiri-6, Greeshma, } \\
\text { Tirupati-2, CS-19, ICG 3608, ICG } \\
\text { 1232, ICG 4477, ICG 3603, ICG } \\
\text { 4113, ICG 1384, TCGS } 1157\end{array}$ \\
\hline 8 & $61-80$ & Narayani (SC) & Narayani (SC) \\
\hline 9 & $81-100$ & TMV-2, JL-24 (SC) & TMV-2, JL-24 (SC) \\
\hline
\end{tabular}

<3: resistant, 3-5: moderately resistant, 6-7: susceptible, 8-9: highly susceptible RC: resistant check, SC: susceptible check 
Table.2 Number of alleles, base pair range produced by the primer in vivo and PIC of polymorphic markers studied in Groundnut genotypes

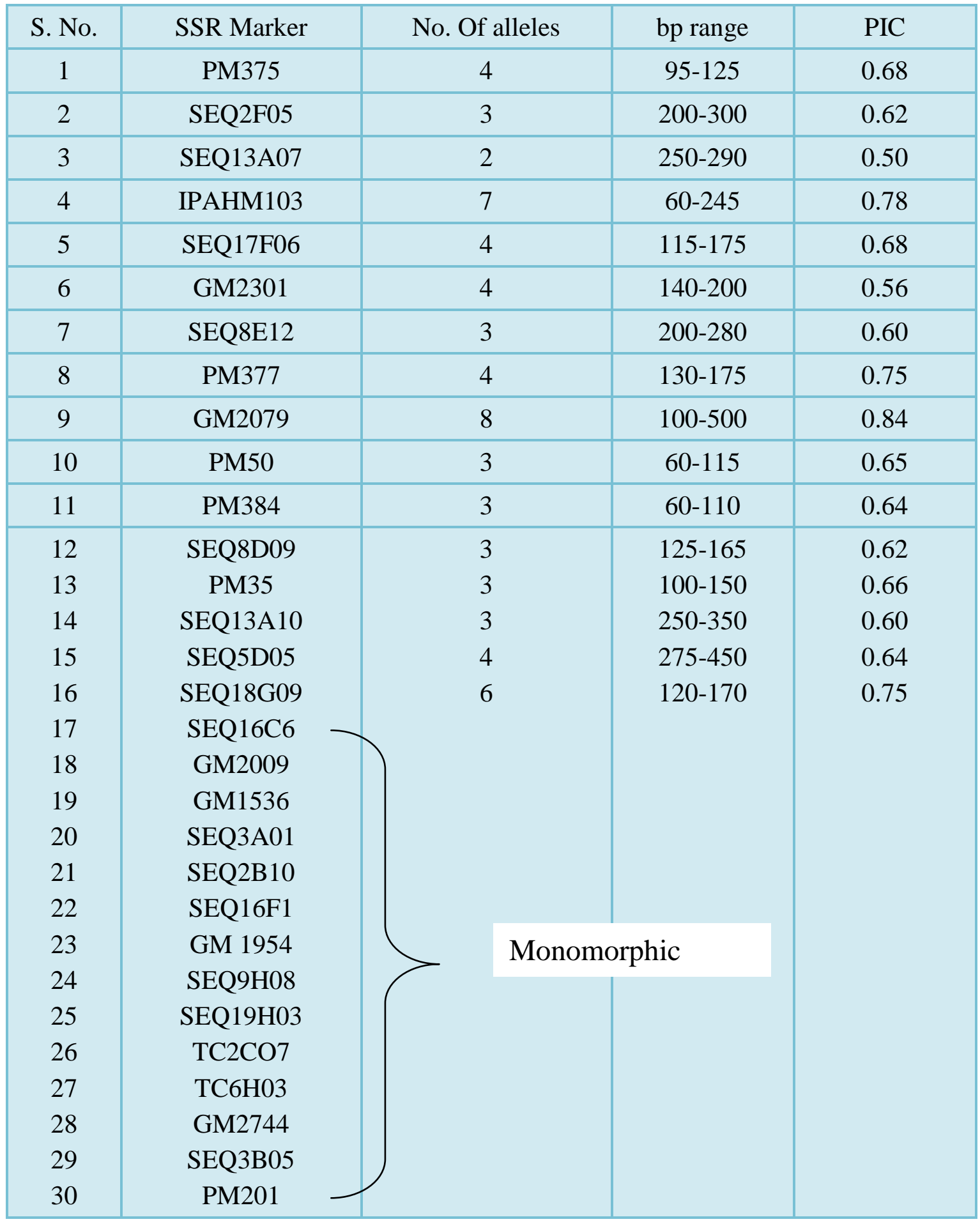


Fig.1 Clustering of Groundnut Genotypes using SPSS Software based on SSR Markers

$\frac{1}{0}$

Dendrogram using Average Linkage (Between Groups)

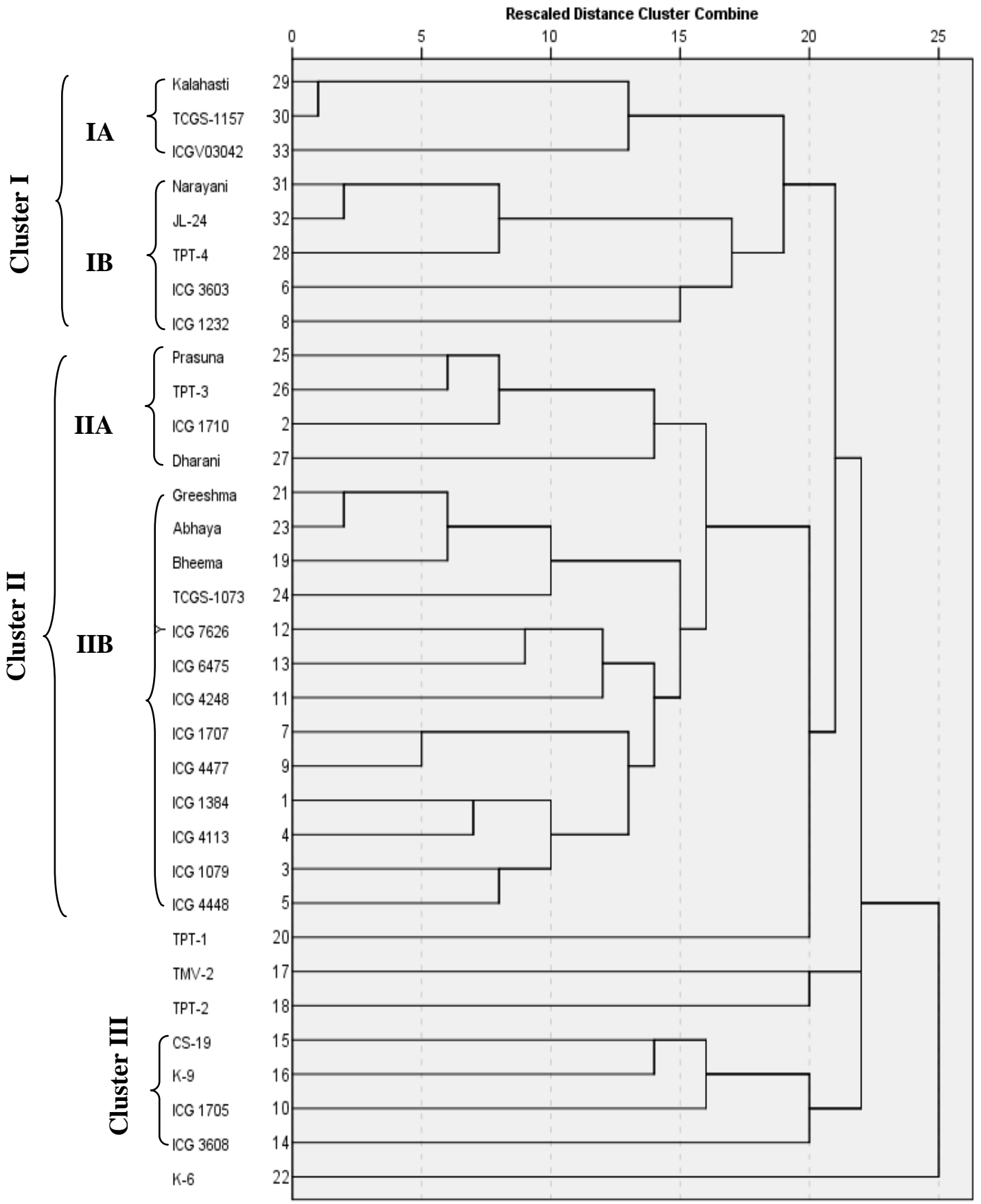


Fig.2 DNA profiles of 19 genotypes of groundnut with SSR marker IPAHM103

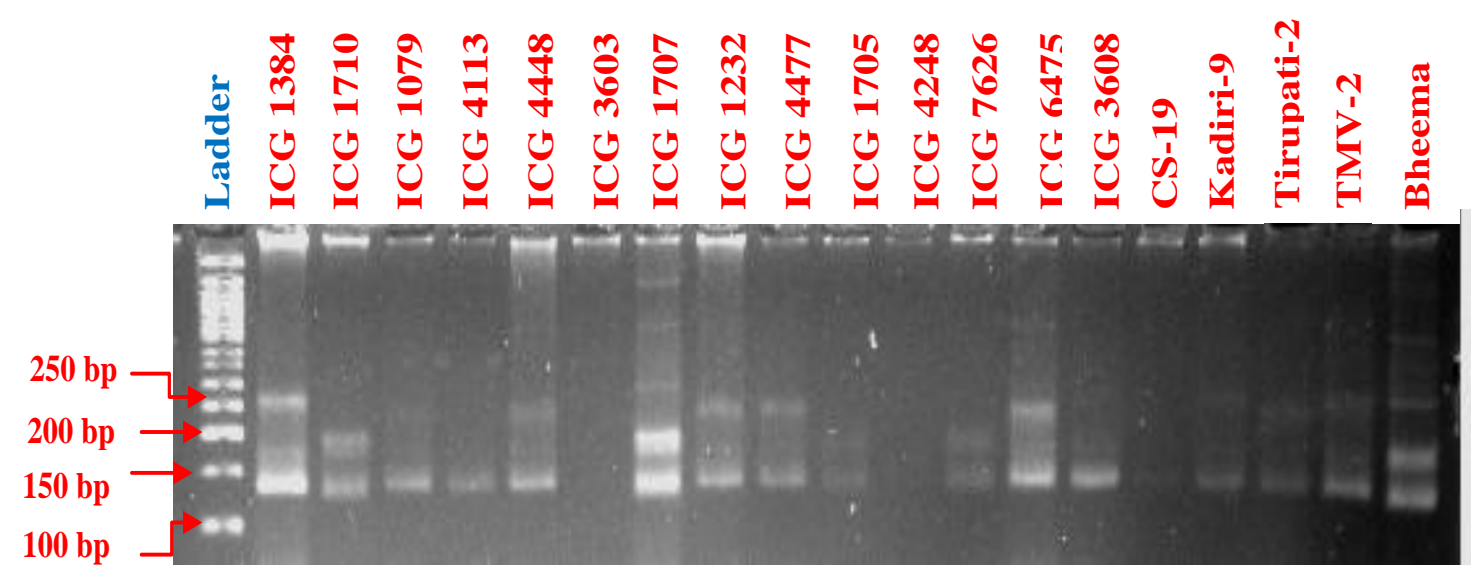

Fig.3 DNA profile of 13 genotypes of groundnut with SSR marker IPAHM103

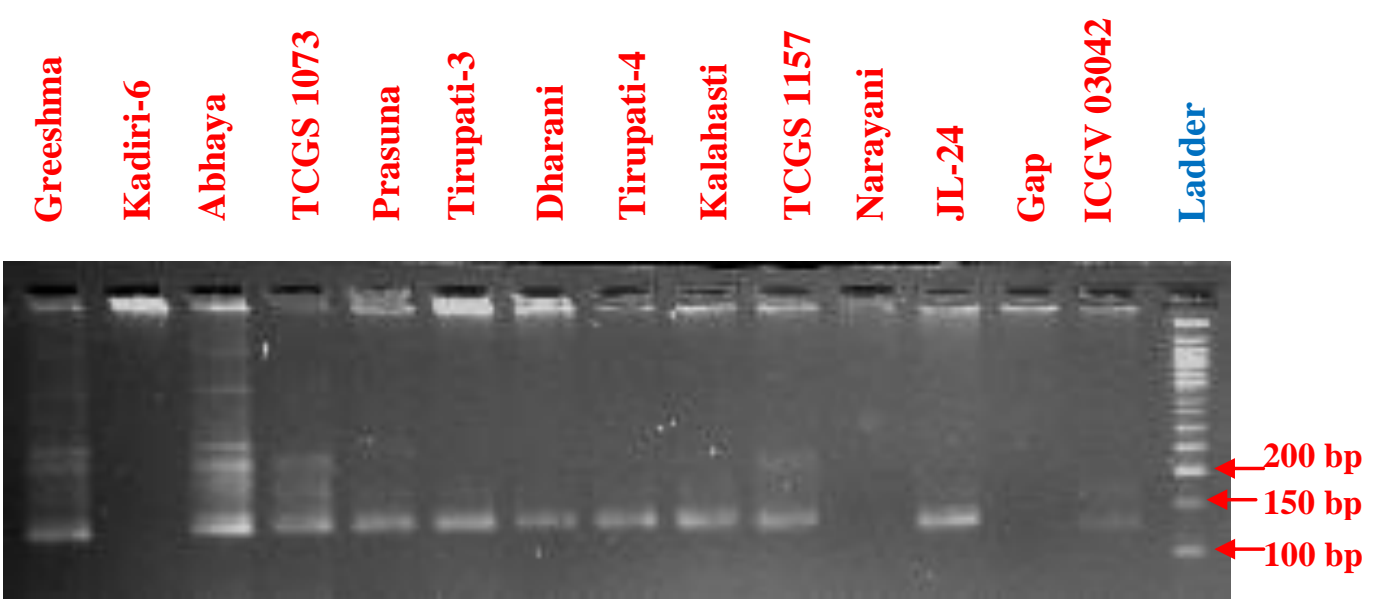

Fig.4 DNA profile of 33 genotypes of groundnut with SSR marker PM375

\section{L $1223445677891011121313 \quad 1415161718192021222324 \quad$ L 252627282930313233}

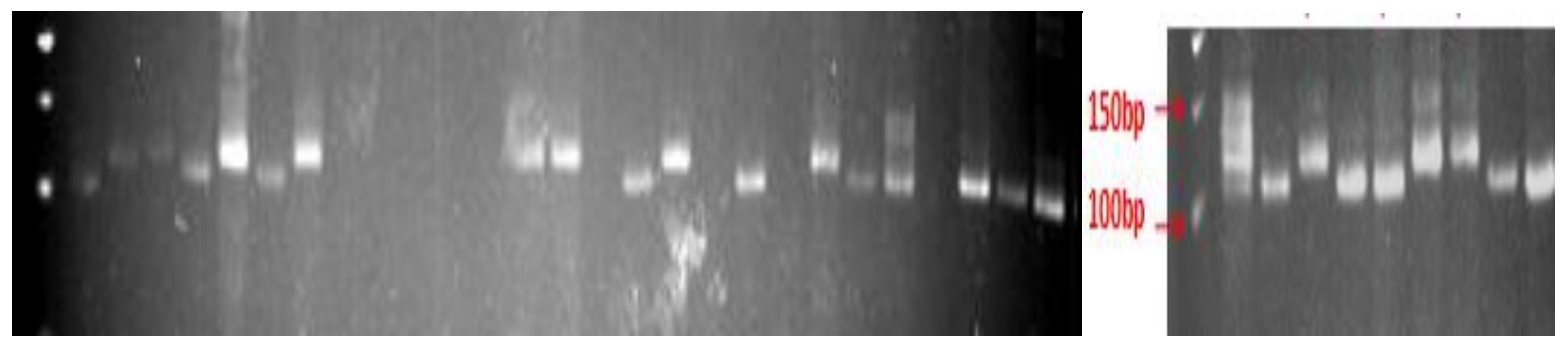

(1= ICG1384, 2= ICG1710, 3= ICG1079, 4= ICG4113, 5= ICG4448, 6= ICG3603, 7= ICG1707, 8= ICG1232, 9= ICG4477, 10= ICG1705, 11= ICG4248, 12= ICG7626, 13= ICG6475, 14= ICG3608, 15= CS19, 16= Kadiri9, 17= Tirupati-2, 18= TMV-2, 19= Bheema, 20= Tirupati $-1,21=$ Greeshma, 22= Kadiri6, 23= Abhaya, 24= TCGS1073, 25= Prasuna, 26= ICGV03042, 27= Prasuna, 27= Tirupati3, 28= Dharani, 29= Tirupati4, 30= Kalahasti, 31= TCGS $1157,32=$ Narayani, 33= JL-24) 
Fig.5 Bar-coding for disease reaction association generated with two SSR markers after electrophoretic separation of DNA fragments

\begin{tabular}{|c|c|c|c|c|c|c|c|c|c|c|c|c|c|c|c|c|c|c|c|c|c|c|c|c|c|c|c|c|}
\hline & $\begin{array}{l}1 \\
3 \\
8 \\
4\end{array}$ & $\begin{array}{l}\mathrm{I} \\
\mathrm{C} \\
\mathrm{G}\end{array}$ & $\begin{array}{l}1 \\
0 \\
7 \\
9\end{array}$ & \begin{tabular}{l|} 
I \\
C \\
G \\
4 \\
4 \\
1 \\
1 \\
3
\end{tabular} & \begin{tabular}{l|l}
$\mathrm{I}$ & \\
$\mathrm{C}$ & \\
$\mathrm{G}$ & \\
4 & \\
4 & \\
4 & \\
8 &
\end{tabular} & $\begin{array}{lll}\mathrm{I} & \mathrm{I} \\
\mathrm{C} & \mathrm{C} \\
\mathrm{G} & \\
3 & \\
3 & \\
6 & 7 \\
0 & 7 \\
3 & 7\end{array}$ & $\begin{array}{ll}\mathrm{I} \\
\mathrm{C} \\
\mathrm{G} \\
\mathrm{G} \\
1 \\
2 \\
3 \\
2 \\
2\end{array}$ & $\begin{array}{l}4 \\
4 \\
7 \\
7\end{array}$ & \begin{tabular}{|l|}
$\mathrm{I}$ \\
$\mathrm{C}$ \\
$\mathrm{G}$ \\
\\
1 \\
7 \\
0 \\
5
\end{tabular} & \begin{tabular}{l|} 
I \\
$\mathrm{C}$ \\
$\mathrm{G}$ \\
4 \\
4 \\
2 \\
4 \\
8
\end{tabular} & \begin{tabular}{l|l}
$\mathrm{I}$ & $\mathrm{I}$ \\
$\mathrm{C}$ & $\mathrm{C}$ \\
$\mathrm{G}$ & $\mathrm{C}$ \\
& \\
7 & 6 \\
6 & 4 \\
2 & 7 \\
6 & 5
\end{tabular} & $\begin{array}{ll}\mathrm{I} & \mathrm{I} \\
\mathrm{C} & \mathrm{C} \\
\mathrm{G} & \mathrm{C} \\
6 & \\
6 & 3 \\
4 & 6 \\
7 & 0 \\
5 & 8\end{array}$ & \begin{tabular}{|c|}
$C$ \\
$S$ \\
- \\
1 \\
9 \\
\end{tabular} & \begin{tabular}{l|}
$\mathrm{K}$ \\
- \\
9
\end{tabular} & \begin{tabular}{l|}
$\mathrm{T}$ \\
$\mathrm{M}$ \\
$\mathrm{V}$ \\
- \\
2
\end{tabular} & $\begin{array}{l}\mathrm{T} \\
\mathrm{P} \\
\mathrm{T} \\
- \\
2\end{array}$ & $\begin{array}{l}\mathrm{B} \\
\mathrm{h} \\
\mathrm{e} \\
\mathrm{e} \\
\mathrm{m} \\
\mathrm{a}\end{array}$ & $\begin{array}{l}\mathrm{T} \\
\mathrm{P} \\
\mathrm{T} \\
- \\
1\end{array}$ & $\begin{array}{l}\mathrm{G} \\
\mathrm{r} \\
\mathrm{e} \\
\mathrm{e} \\
\mathrm{s} \\
\mathrm{h} \\
\mathrm{m} \\
\mathrm{a}\end{array}$ & $\begin{array}{ll}\mathrm{K} & \mathrm{A} \\
- & \mathrm{b} \\
6 & \mathrm{~h} \\
& \mathrm{a} \\
\mathrm{y}\end{array}$ & \begin{tabular}{l|l}
$\mathrm{A}$ & $\mathrm{T}$ \\
$\mathrm{b}$ & $\mathrm{C}$ \\
$\mathrm{h}$ & $\mathrm{G}$ \\
$\mathrm{a}$ & $\mathrm{S}$ \\
$\mathrm{y}$ & - \\
$\mathrm{a}$ & 1 \\
& 0 \\
& \\
\end{tabular} & \begin{tabular}{|l}
$\mathrm{P}$ \\
$\mathrm{r}$ \\
$\mathrm{a}$ \\
$\mathrm{s}$ \\
$\mathrm{u}$ \\
$\mathrm{n}$ \\
$\mathrm{a}$
\end{tabular} & \begin{tabular}{|c|}
$\mathrm{T}$ \\
$\mathrm{P}$ \\
$\mathrm{T}$ \\
- \\
3 \\
\end{tabular} & \begin{tabular}{c|c}
$\mathrm{D}$ & $\mathrm{T}$ \\
$\mathrm{h}$ & $\mathrm{F}$ \\
$\mathrm{a}$ & $\mathrm{T}$ \\
$\mathrm{r}$ & - \\
$\mathrm{a}$ & 4 \\
$\mathrm{n}$ & 4 \\
$\mathrm{i}$ & -
\end{tabular} & \begin{tabular}{c|c}
$\mathrm{T}$ & $\mathrm{K}$ \\
$\mathrm{P}$ & $\mathrm{a}$ \\
$\mathrm{T}$ & 1 \\
- & $\mathrm{a}$ \\
4 & $\mathrm{~h}$ \\
& $\mathrm{a}$ \\
$\mathrm{a}$ & $\mathrm{s}$ \\
$\mathrm{t}$ \\
$\mathrm{i}$
\end{tabular} & \begin{tabular}{|c|}
$\mathrm{T}$ \\
$\mathrm{C}$ \\
$\mathrm{G}$ \\
$\mathrm{S}$ \\
- \\
1 \\
1 \\
5 \\
7
\end{tabular} & \begin{tabular}{l|}
$\mathrm{J}$ \\
$\mathrm{L}$ \\
- \\
2 \\
4
\end{tabular} & $\begin{array}{l}\mathrm{N} \\
\mathrm{a} \\
\mathrm{r} \\
\mathrm{a} \\
\mathrm{y} \\
\mathrm{a} \\
\mathrm{n} \\
\mathrm{i}\end{array}$ \\
\hline $\begin{array}{l}\text { Disease } \\
\text { scoring- rust }\end{array}$ & 7 & 4 & 5 & 7 & 6 & 7 & 7 & 7 & 6 & 6 & 6 & \begin{tabular}{l|l}
5 & 7
\end{tabular} & 7 & 6 & 9 & 7 & 5 & 7 & 7 & 7 & 7 & 7 & 7 & 7 & 7 & 7 & 9 & 8 \\
\hline $\begin{array}{l}\text { IPAHM103 } \\
\text { (140bp) }\end{array}$ & & & & & & & & & & & & & & & & & & & & & & & & & & & & \\
\hline $\begin{array}{l}\text { IPAHM103 } \\
\text { (180bp) }\end{array}$ & & & & & & & & & & & & & & & & & & & & & & & & & & & & \\
\hline PM375(105bp) & & & & & & & & & & & & & & & & & & & & & & & & & & & & \\
\hline PM375(118bp) & & & & & & & & & & & & & & & & & & & & & & & & & & & & \\
\hline $\begin{array}{l}\text { Disease } \\
\text { scoring- LLS }\end{array}$ & 6 & 4 & 5 & 6 & 5 & 7 & 7 & 6 & 5 & 5 & \begin{tabular}{l|l}
6 & 5 \\
\end{tabular} & 7 & 7 & 6 & 9 & 6 & 6 & 7 & 7 & 7 & 7 & 7 & 6 & 7 & 6 & 7 & 9 & 8 \\
\hline $\begin{array}{l}\text { IPAHM103 } \\
\text { (140bp) }\end{array}$ & & & & & & & & & & & & & & & & & & & & & & & & & & & & \\
\hline $\begin{array}{l}\text { IPAHM103 } \\
\text { (180bp) }\end{array}$ & & & & & & & & & & & & & & & & & & & & & & & & & & & & \\
\hline PM375(105bp) & & & & & & & & & & & & & & & & & & & & & & & & & & & & \\
\hline PM375(118bp) & & & & & & & & & & & & & & & & & & & & & & & & & & & & \\
\hline
\end{tabular}

Most probably the resistant allele (Resistant Gene Analogue RGA) might have involved in conferring general resistance to a wide variety of biotic stresses ranging from fungi belonging to different genera to nematodes. Therefore, this RGA can be a candidate gene in MAS and can be employed in broad spectrum resistance breeding programmes. Further, the genotyping is based on only 30 SSR markers and more number of markers covering the entire genome is required for more authentic genotyping of groundnut genotypes for LLS and rust phenotypes.

\section{Acknowledgements}

We acknowledge ICAR- Indian Institute of Groundnut Research, Junagadh and RARS, Tirupati for providing the genotypes used in this study. We also acknowledge ANGRAU for providing research facilities and Bayer fellowship to the First Author.

\section{References}

Anderson, JA, Churchill, GA, Sutrique, JE, Tanksley, SD and Sorrells, ME. 1993. Optimizing parental selection for genetic linkage maps. Genome, 36: 181186.

Bromfield, KR and Bailey, WK. 1972. Inheritance of resistance to Puccinia arachidis in peanut. Phytopathology, 62: 748.

Cuc, LM, Mace, EM, Crouch, JH, Quang, VD, Long, TD and Varshney, RK. 2008. Isolation and characterization of novel microsatellite markers and their 
application for diversity assessment in cultivated groundnut (Arachis hypogaea). BMC Plant Biology, 8:55.

Doyle, JJ and Doyle, JL. 1990. Isolation of plant DNA from fresh leaf tissue. Focus, 12: 13-15.

Ferguson, ME, Burow, MD, Schulze, SR, Bramel, PJ, Paterson, AH, Kresovich, S, Mitchell, S. 2004. Microsatellite identification and characterization in peanut (A. hypogaea L.). Theoretical and Applied Genetics, 108: 1064-1070.

Gaikpa, DS, Akromah, R, Asibuo, JY and Nyadanu, D. 2015. Studies on molecular variation in commercially cultivated groundnuts (Arachis hypogaea L.) using SSR markers. The International Journal of Science and Technology, 3(2): 80-85.

Gautami, B, Ravi, K, Lakshmi, NM, Hoisington, DA and Varshney, RK. 2009. Novel set of groundnut SSRs for genetic diversity and interspecific transferability. International Journal of Integrated Biology, 7:100-106.

Gupta, PK and Varshney, RK. 2000. The development and use of microsatellite markers for genetic analysis and plant breeding with emphasis on bread wheat. Euphytica, 113: 163-185.

Halward, TM, Stalker, HT, Larue, EA and Kochert, G. 1991. Genetic variation detectable with molecular markers among unadapted germplasm resources of cultivated peanut and related wild species. Genome, 34: 1013-1020.

He, G, Meng, R, Gao, H, Guo, B, Gao, G, Newman, R, Pittman, N and Prakash, CS. 2005. Simple sequence repeats markers for botanical varieties of cultivated peanut (Arachis hypogaea L.). Euphytica, 142: 131-136.

Hildebrand, CE, Torney, DC and Wagner, RP. 1992. Informativeness of polymorphic DNA markers. Los Alamos Science, 20:100-102.
Jaccard, P. 1908. Nouvelles researchers sur la distribution florale Société. Vaudoise des Science Naturelles, 44:22-27.

Mace, ES, Phong, DT, Upadhyaya, HD, Chandra, S and Crouch, JH. 2006. SSR analysis of cultivated groundnut (Arachis hypogaea L.) germplasm resistant to rust and late leaf spot diseases. Euphytica, 152: 317-330.

Mondal, S and Badigannavar, AM. 2009. Molecular diversity and association of SSR markers to rust and late spot resistance in cultivated groundnut (Arachis hypogaea L.). Plant Breeding, 129: 68-71.

Norusis, M. 2004. SPSS 13.0 Statistical Procedures Companion. Upper SaddleRiver, N.J.: Prentice Hall, Inc., USA.

Oteng-Frimpong, R, Sriswathi, M, Ntare, BR and Dakora, FD. 2015. Assessing the genetic diversity of 48 groundnut (Arachis hypogaea L.) genotypes in the Guinea savanna agro-ecology of Ghana, using microsatellite-based markers. African Journal of Biotechnology, 14 (32): 2484-2493.

Paramasivam, K, Jayasekhar, M, Rajasekharan, $\mathrm{R}$ and Veerabadhiran, $\mathrm{P}$. 1990. Inheritance of rust resistance in groundnut (Arachis hypogaea L.). Madras Agricultural Journal, 77: 5052.

Seijo, GJ, Lavia, GI, Fernández, A, Krapovickas, A, Ducasse, D and Moscone, EA. 2004. Physical mapping of the $5 \mathrm{~S}$ and $18 \mathrm{~S}-25 \mathrm{~S}$ rRNA genes by FISH as evidence that Arachis duranensis and $A$. ipaënsis are the wild diploid progenitors of $A$. hypogaea (Leguminosae). American Journal of Botany, 91: 1294-1303.

Subrahmanyam, P, Rao, VR, McDonald, D, Moss, JP and Gibbons, RW. 1989. Origins of resistance to rust and late leaf spot in peanut (Arachis hypogaea Fabaceae). Economic Botany, 43: 444- 
455.

Subrahmanyam, P, McDonald, D, Waliyar, F, Reddy, LJ, Nigam, SN, Gibbons, RW, Ramanatha Rao, VR, Singh, AK, Pande, S, Reddy, PM and Subba Rao, PV. 1995. Screening methods and sources of resistance to rust and late leaf spot of groundnut. Information Bulletin 47, Patancheru, Andhra Pradesh: ICRISAT, 24.

Sudini, H, Upadhyaya, HD, Reddy, SV, Naga Mangala, U, Rathore, A and Vijaykrishna Kumar, K. 2015. Resistance to late leaf spot and rust diseases in ICRISAT's mini core collection of peanut (Arachis hypogaea L.). Australian Journal of Plant Pathology, 44 (5): 557-566.

Sujay, V, Gowda, MVC, Pandey, MK, Bhat, RS, Khedikar, YP, Nadaf, HL, Gautami,
B, Sarvamangala, C, Lingaraju, S, Radhakrishan, T, Knapp, SJ and Varshney, RK. 2012. Quantitative trait locus analysis and construction of consensus genetic map for foliar disease resistance based on two recombinant inbred line populations in cultivated groundnut (Arachis hypogaea L.). Molecular Breeding, 30: 773-788.

Tiwari, SP, Ghewande, MP and Misra, DP. 1984. Inheritance of resistance to rust and late leaf spot in groundnut (Arachis hypogaea L.). Journal of Cytology and Genetics, 19: 97-101.

Young, ND, Weeden, NF and Kochert, G. 1996. Genome mapping in legumes (Family Fabaceae). In: Paterson, A.H., (ed.) Genome Mapping in Plants. Landes Biomedical Press, Austin, Texas, USA. pp 212-277.

\section{How to cite this article:}

Anamika Roy, M. Lal Ahamed, Y. Amaravathi, K. Viswanath, J.P.B. Dayal and Sreekanth, B. 2018. Diversity Analysis and Assessment of Association of SSR Markers to Late Leaf Spot and Rust Resistance in Groundnut (Arachis hypogaea L.). Int.J.Curr.Microbiol.App.Sci. 7(08): 3620-3630. doi: https://doi.org/10.20546/ijcmas.2018.708.366 